\title{
Endogenous losses and true digestibility of phosphorus in rice bran with or without phytase determined with piglets
}

\author{
Perdas endógenas e digestibilidade verdadeira do fósforo do farelo \\ de arroz integral com ou sem fitase determinado com leitões
}

\author{
Walter Lucca ${ }^{\mathrm{I}}$ Débora Aline Alves II Leonardo Tombesi da Rocha ${ }^{\text {III }}$ Graciele Dalise Shirmann ${ }^{\text {III }}$ \\ Claudiele Aparecida do Santos Camargo ${ }^{\mathrm{III}}$ Andriele Medianeira Figueiredo ${ }^{\mathrm{III}}$ \\ Irineo Zanella ${ }^{\mathrm{III}}$ Vladimir de Oliveira ${ }^{\mathrm{II}}$
}

\section{ABSTRACT}

The aim of this study was to determine endogenous losses and true total digestibility of phosphorus $(P)$ in piglets fed with diets containing rice bran (RB), and supplemented or not with phytase. The experiment was divided into three periods of 12 days each, seven for adaptation and five for total feces collection, with an interval of three days between periods. Twelve barrows with average body weights of $13.40 \pm 1.00 \mathrm{~kg}$ at 46 days of age were distributed among six treatments consisting of diets formulated with three levels of $R B(5 \%, 10 \%$, and $20 \%)$ with or without the addition of $750 F T U \mathrm{~kg}^{-1}$ of phytase. The amount of total daily feed was divided into four daily meals and water was available ad libitum. The method of total feces collection was used with ferric oxide as the fecal marker. The total consumption of $P$ of $R B$ origin was $0.37,0.85$ and $1.73 \mathrm{gd}^{-1}$ for concentrations of $5 \%, 10 \%$ and $20 \%$ of $R B$, respectively. Both $R B$ and phytase levels had an effect on the apparent digestibility of $P$ in $R B$. Results of the regression analysis of ingested $P$ originating from the $R B$ and absorbed $P$ indicated endogenous losses of $527 \mathrm{mg}$ of $\mathrm{Pkg}^{-1}$ of dry matter intake, independent of phytase. Additionally, the true digestibility of $P$ in $R B$ was $47 \%$, and it was not influenced by the inclusion of phytase. We concluded that the addition of 750FTU of phytase does not affect endogenous losses or the true digestibility of $P$ in $R B$.

Key words: endogenous losses, phytase, regression, total collection.

\section{RESUMO}

$O$ objetivo do estudo foi determinar as perdas endógenas e a digestibilidade total verdadeira do fósforo $(P$ do farelo de arroz integral (FAI) com ou sem suplementação de fitase. $O$ experimento foi dividido em três períodos de 12 dias cada, sendo, sete de adaptação e cinco de coleta total de fezes, com um intervalo de três dias entre os periodos. Utilizaram-se 12

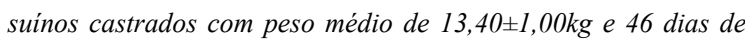
idade, distribuidos em seis tratamentos que consistiram de dietas formuladas com três níveis de FAI (5, 10 e 20\%), com adição ou não de $750 F_{T U \mathrm{~kg}^{-1}}$ de fitase. A quantidade de ração total foi dividida em quatro refeições diárias e a água disponibilizada à vontade. Foi utilizado o método de coleta total de fezes, utilizando o óxido férrico como marcador fecal. O consumo de P com origem no FAI foi de 0,37, 0,85 e 1,73gd para os teores de 5, 10 e 20\% de FAI, respectivamente. Tanto os niveis FAI como a fitase exerceram efeitos na digestibilidade aparente do $P$ do FAI. Os resultados da análise de regressão entre $P$ ingerido com origem no FAI e

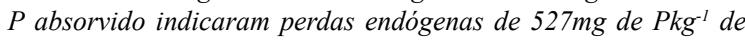
matéria seca ingerida (DMI), independente do uso da fitase. Além disso, a digestibilidade verdadeira do P no FAI foi de $47 \%$ e não sofreu influência da inclusão de fitase. Conclui-se que a adição de $750 F T U$ de fitase não influencia nas perdas endógenas e nem na digestibilidade verdadeira de P no FAI.

Palavras-chave: coleta total, fitase, perdas endógenas, regressão.

\section{INTRODUCTION}

The amount of total phosphorus (P) in the principal raw materials used for pig diet formulation is variable, as is the proportion of total $P$ that is bioavailable (ROSTAGNO et al., 2011). One of the measures used to express $\mathrm{P}$ content in food is digestibility, which indicates the digestive disappearance of P (NRC, 2012). Despite to observed with amino acids, the large intestine seems to have little influence on P homeostasis; consequently, total

Instituto Federal (IFRS), Campus Sertão, Sertão, RS, Brasil.

"Programa de Pós-graduação em Zootecnia, Universidade Federal de Pelotas (UFPEL), Pelotas, RS, Brasil.

IIIDepartamento de Zootecnia, Universidade Federal de Santa Maria (UFSM), 97105-900, Santa Maria, RS, Brasil. E-mail: vladimir.oliveira@ufsm.br. "Corresponding author. 
or fecal digestibility is a technically and economically viable alternative to measure $\mathrm{P}$ digestion (FAN et al., 2001; BOHLKE et al., 2005). However, it is necessary to make corrections for endogenous losses of $\mathrm{P}$ because not all $\mathrm{P}$ determined in feces originates from food (ALMEIDA \& STEIN, 2012). Therefore, it is possible to calculate the true digestibility of P. True digestibility values are more useful in pig diet formulation, because of high variability in apparent digestibility data, even when considering a single food (FAN et al., 2001). Moreover, the apparent digestibility values of $\mathrm{P}$, estimated for individual foods, are not always additive (ALMEIDA \& STEIN, 2012), and this is a fundamental premise for ration formulation using the linear method.

Rice bran $(\mathrm{RB})$ can be included in proportions ranging from $20 \%$ to $30 \%$ of pigs' diet, in the nursery phase (GOMES et al., 2012).Total phosphorus content of $\mathrm{RB}$ is high $(1.67 \%)$ although about $80 \%$ is in the form of phytate, which is largely unavailable for poultry and swine (ROSTAGNO et al., 2011). Since the mid90s, phytase has been used by animal feed industry to "improve" the bioavailability of $\mathrm{P}$, calcium, amino acids and energy through phytate hydrolysis. Moreover, phytase reduce the excretion of $\mathrm{P}$ to the environment (DERSJANT-LI et al., 2014). Because of the possibility of including RB in piglets' diet and its high concentration of phytate, a study was conducted to determine the true total digestibility of $\mathrm{P}$ from $\mathrm{RB}$, with or without the addition of phytase for piglets in the nursery phase.

\section{MATERIALS AND METHODS}

Twelve castrated pigs were used, in the nursery phase, with an average live weight of $13.40 \pm 1.00 \mathrm{~kg}$ at 46 days old. The animals stayed in metabolic cages maintained in a controlled environment, at an average temperature of $22^{\circ} \mathrm{C}$. The experimental period was divided into three blocks lasting 12 days (seven days for adaptation to experimental conditions and five days for fecal collection). Between each 12-day period, a formulated diet was given to meet the animals' nutritional requirements according to ROSTAGNO et al. (2011).

Six semi-purified experimental diets were prepared (Table 1), with two levels of phytase $\left(0.750 \mathrm{FTUkg}^{-1}\right)$ and three levels of RB $(5 \%, 10 \%$ and $20 \%$ ) distributed among six treatments. Due to the use of dried blood plasma (PS; AP920), which contains P as a source of amino acids, a constant inclusion of RB levels was adopted. This strategy aims to ensure similar proportions of dietary P from RB and PS. Limestone and purified cellulose were used to maintain the $\mathrm{Ca}: \mathrm{P}$ ratio
Table 1 - Composition of experimental diets.

\begin{tabular}{|c|c|c|c|}
\hline \multirow{2}{*}{ Ingredients $(\%)$} & \multicolumn{3}{|c|}{ - } \\
\hline & $5 \% \mathrm{RB}$ & $10 \% \mathrm{RB}$ & $20 \% \mathrm{RB}$ \\
\hline Rice bran & 5.00 & 10.00 & 20.00 \\
\hline Starch $^{1}$ & 69.45 & 62.25 & 47.40 \\
\hline Sugar & 15.00 & 15.00 & 15.00 \\
\hline Blood plasma & 3.75 & 7.50 & 15.00 \\
\hline Cellulose & 3.50 & 2.30 & 0.00 \\
\hline Soya oil & 0.30 & 0.10 & 0.00 \\
\hline Limestone & 0.50 & 1.00 & 2.00 \\
\hline Salt & 0.30 & 0.30 & 0.30 \\
\hline Premix $^{2}$ & 0.10 & 0.10 & 0.10 \\
\hline L- lysine & 0.90 & 0.60 & 0.00 \\
\hline DL- methionine & 0.50 & 0.35 & 0.20 \\
\hline L- tryptophan & 0.20 & 0.10 & 0.00 \\
\hline L- threonine & 0.50 & 0.40 & 0.00 \\
\hline \multirow[t]{2}{*}{ Total } & 100 & 100 & 100 \\
\hline & \multicolumn{3}{|c|}{----------Calculated values---------- } \\
\hline Metabolizable energy. $\mathrm{kcalkg}^{-1}$ & 3434 & 3423 & 3418 \\
\hline Crude protein $(\%)^{(3)}$ & 5.50 & 7.88 & 13.57 \\
\hline Lysine (\%) & 0.98 & 0.99 & 1.03 \\
\hline Methionine (\%) & 0.53 & 0.43 & 0.36 \\
\hline Methionine+ Cystine (\%) & 0.62 & 0.59 & 0.69 \\
\hline Threonine (\%) & 0.66 & 0.74 & 0.68 \\
\hline Tryptophan (\%) & 0.25 & 0.20 & 0.20 \\
\hline $\operatorname{NDF}(\%)^{(3)}$ & 4.22 & 4.22 & 4.30 \\
\hline Calcium $(\%)^{(3)}$ & 0.21 & 0.41 & 0.82 \\
\hline Total Phosphorus(\%) & 0.10 & 0.20 & 0.40 \\
\hline $\mathrm{Ca}: \mathrm{P}(\%)$ & 2.04 & 2.04 & 2.04 \\
\hline Lys:ME (\%) & 2.85 & 2.91 & 3.01 \\
\hline P-RB (\%) & 0.84 & 1.67 & 3.34 \\
\hline P-Plasma(\%) & 0.17 & 0.34 & 0.68 \\
\hline P-Plasma/P-RB & 0.20 & 0.20 & 0.20 \\
\hline
\end{tabular}

${ }^{(1)}$ Inclusion of $7.5 \mathrm{~g}$ of Natuphos phytase $\left(750 \mathrm{FTUkg}^{-1}\right)$ replacing the starch in treatments with phytase. ${ }^{(2)}$ Quantitykg ${ }^{-1}$ of mineral and vitamin mixture Vit A 1.750.000UI; Vit D3 300.000UI; Vit E $3.000 \mathrm{mg}$; Vit K3 400mg; Vit B1 250mg; Vit B2 750mg; Vit B6 250mg; Vit B12 3000mcg; niacin 5000mg. Pantothenic acid $3000 \mathrm{mg}$; choline $3000 \mathrm{mg}$; antioxidant $3750 \mathrm{mg}$; Fe. $80000 \mathrm{mg}$; Cu. 12.000mg; Mn. 70.000mg; Zn. 100.000mg. ${ }^{(3)}$ Analyzed values.

and the same neutral detergent fiber (NDF) between diets, respectively. The animals received mineral and vitamin supplements.

Experimental diets were prepared according to the concept of ideal protein. In the experiment, a phytase was used from the fungus Aspergillus Niger. The total amount of food provided was based on the metabolic weight $\left(\mathrm{kg}^{0.75}\right)$ of the animals and distributed over four meals per day, and water was available for consumption $a d$ libitum. Wasted feed was dried in a forced ventilation 
oven at $60^{\circ} \mathrm{C}$ for $72 \mathrm{~h}$, weighed and deducted from the total amount provided.

The method of total feces collection was used with ferric oxide serving as a fecal marker to study digestibility. Feces were collected twice per day, at 8:00 am and 3:00 pm, packed in plastic bags and stored in a freezer at $-18^{\circ} \mathrm{C}$. At the end of each block, the material was thawed, homogenized, sampled, weighed and predried in a forced ventilation oven at $60^{\circ} \mathrm{C}$, for $72 \mathrm{~h}$.

Chemical analyses were performed according to methods outlined in AOAC, 2005. The samples were analyzed for the following components: dry matter (DM), mineral matter (MM), organic matter $(\mathrm{OM}), \mathrm{NDF}$, crude protein $(\mathrm{CP})$ and $\mathrm{P}$ in ingredients, feed, and excretions. In P analysis, the methodology of wet digestion was used, and both readings were taken using a spectrophotometer. Formulas described by ALMEIDA \& STEIN (2011) were used to calculate digestibility coefficients, assuming that $\mathrm{P}$ from PS had a digestibility of $92 \%$ (ROSTAGNO et al., 2011).

A $2 \times 3$, randomized factorial block design was used with two levels of phytase, three levels of $\mathrm{RB}$, and six replications per treatment. The animal was considered an experimental unit. Interactions between main effects were not significant; therefore it was excluded from the statistical model. Results were subjected to analysis of variance and linear regression using the statistical program MINITAB (2013).

\section{RESULTS AND DISCUSSION}

The animals remained healthy during the experimental period and feces samples were obtained without any problem. Dry matter intake (DMI) was not affected $(\mathrm{P}>0.05)$ by $\mathrm{RB}$ or phytase and average individual consumption was $378 \mathrm{gd}^{-1}$ or $55 \mathrm{gkg}^{-1} \mathrm{BW}^{0.75}$ (Table 2). Inclusion of RB was associated with a linear increase $(\mathrm{P}<0.01)$ in the excreted dry matter $(\mathrm{DME})$, and a reduction $(\mathrm{P}<0.01)$ in digestible dry matter (DMD). Data indicated that for each percentage point of $\mathrm{RB}$ increase, there was a decrease $(\mathrm{P}<0.01)$ of 0.27 percentage points in the DMD of the diet. That effect occurred despite diets had their NDF content equalized with purified cellulose in an attempt to reduce the effect of fiber on DMD. However, it is possible that differences in fiber characteristics between diets, for example, relation between soluble and insoluble fiber, were the cause of the reduction in DMD.

The total apparent digestibility coefficient (ADC) of $\mathrm{P}$ coming from $\mathrm{RB}\left(\mathrm{P}_{\mathrm{RB}}\right)$ increased with the inclusion of RB (Table 3), and there was a trend of phytase effect in that variable. The negative values of $\mathrm{RB}$ digestible $\mathrm{P}\left(\mathrm{PDIG}_{\mathrm{RB}}\right)$ that were observed when adding $5 \% \mathrm{RB}$ occurred because the amount of $\mathrm{P}$ in feces was larger than the ingested content (YANG et al., 2007).

The addition of phytase did not alter $(\mathrm{P}>0.05)$ the linear relation intercept between $\mathrm{P}$ absorbed coming from $\mathrm{RB}\left(\mathrm{PABS}_{\mathrm{RB}}\right)$ and $\mathrm{P}$ ingested coming from $\mathrm{RB}\left(\mathrm{PING}_{\mathrm{RB}}\right)\left(\mathrm{mgkg}^{-1} \mathrm{DMI}\right)$ (Figure 1), indicating that phytase had no effect on endogenous losses of phosphorus. These results probably are associated with the fact that the substrate of phytase is phosphorus from phytate which is absent on EBLP (SHEN et al., 2002). Phytase addition did not influence endogenous $\mathrm{P}$ losses in diets containing increasing levels of canola or soybean meal (AKINMUSIRE \& ADEOLA, 2009).

The average estimate of endogenous $\mathrm{P}$ losses was 527mgkg DMI [(663+391)/2)], a value

Table 2 - Body weight, intake, excretion and digestibility of dry matter, and phosphorus balance of diet $\left(\mathrm{gd}^{-1}\right)$ for piglets fed with diets containing phytase and rice bran (RB) with inclusion levels of 5, 10 and $20 \%$.

\begin{tabular}{|c|c|c|c|c|c|c|c|c|c|}
\hline \multirow{2}{*}{ Phytase/RB } & \multicolumn{3}{|c|}{-----(0 FTUkg $\left.{ }^{-1}\right)-$} & \multicolumn{3}{|c|}{-(750 FTUkg $\left.{ }^{-1}\right)$} & \multicolumn{3}{|c|}{ 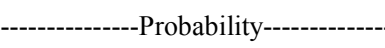 } \\
\hline & 5 & 10 & 20 & 5 & 10 & 20 & SEM & Phytase & $\mathrm{RB}$ \\
\hline ABW (kg) & 11.39 & 13.86 & 13.33 & 12.87 & 14.63 & 14.21 & 0.52 & 0.11 & 0.01 \\
\hline DMI $\left(\mathrm{gd}^{-1}\right)$ & 379.40 & 394.87 & 352.19 & 346.78 & 387.03 & 405.30 & 17.87 & 0.81 & 0.32 \\
\hline $\operatorname{DME}\left(\mathrm{gd}^{-1}\right)$ & 16.12 & 28.66 & 36.45 & 18.15 & 29.56 & 39.34 & 3.77 & 0.53 & 0.01 \\
\hline DMD (\%) & 95.32 & 93.20 & 90.76 & 94.53 & 93.47 & 90.89 & 0.79 & 0.84 & 0.00 \\
\hline $\mathrm{PING}_{\mathrm{D}}\left(\mathrm{gd}^{-1}\right)$ & 0.53 & 1.28 & 2.45 & 0.57 & 1.27 & 2.69 & 0.13 & 0.40 & 0.00 \\
\hline $\operatorname{PEXC}_{\mathrm{D}}\left(\mathrm{gd}^{-1}\right)$ & 0.44 & 0.75 & 1.21 & 0.45 & 0.59 & 1.22 & 0.10 & 0.63 & 0.00 \\
\hline $\mathrm{PABS}_{\mathrm{D}}\left(\mathrm{gd}^{-1}\right)$ & 0.01 & 0.55 & 1.23 & 0.12 & 0.68 & 1.47 & 0.13 & 0.24 & 0.00 \\
\hline $\mathrm{PDIG}_{\mathrm{D}}(\%)$ & 11.71 & 40.29 & 49.63 & 25.58 & 59.01 & 53.85 & 6.25 & 0.05 & 0.00 \\
\hline
\end{tabular}

ABW (kg) - Average body weight; DMI $\left(\mathrm{gd}^{-1}\right)$ - Dry matter intake; DME $\left(\mathrm{gd}^{-1}\right)$ - Excreted dry matter; DMD $(\%)-\mathrm{Digestible}$ dry matter; $\mathrm{PING}_{\mathrm{D}}\left(\mathrm{gd}^{-1}\right)$ - Ingested phosphorus from diet; $\mathrm{PEXC}_{\mathrm{D}}\left(\mathrm{gd}^{-1}\right)-$ Excreted phosphorus from diet; $\mathrm{PABS}_{\mathrm{D}}\left(\mathrm{gd}^{-1}\right)-\mathrm{Absorbed}$ phosphorus; $\mathrm{PDIG}$ (\%) - Digestible Phosphorus from diet; Linear Regression $(\mathrm{P}<0.05)$. 
Table 3 - Phosphorus balance $\left(\mathrm{gd}^{-1}\right)$ of rice bran $(\mathrm{RB})$ from piglets fed diets containing phytase and $\mathrm{RB}$ with inclusion levels of 5 , 10 and $20 \%$.

\begin{tabular}{|c|c|c|c|c|c|c|c|c|c|}
\hline \multirow{2}{*}{$\begin{array}{l}\text { Phytase } \\
\text { RB }\end{array}$} & \multicolumn{3}{|c|}{ 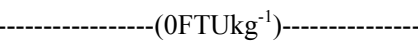 } & \multicolumn{3}{|c|}{ (750FTUkg $\left.{ }^{-1}\right)---$} & \multicolumn{3}{|c|}{--------------'Probability------------- } \\
\hline & 5 & 10 & 20 & 5 & 10 & 20 & SEM & Phytase & $\mathrm{RB}$ \\
\hline $\mathrm{PING}_{\mathrm{RB}}\left(\mathrm{gd}^{-1}\right)^{*}$ & 0.36 & 0.86 & 1.64 & 0.38 & 0.85 & 1.81 & 0.08 & 0.39 & 0.01 \\
\hline $\operatorname{PEXC} C_{\mathrm{RB}}\left(\mathrm{gd}^{-1}\right)^{*}$ & 0.42 & 0.68 & 1.13 & 0.43 & 0.55 & 1.13 & 0.10 & 0.60 & 0.01 \\
\hline $\operatorname{PABS}_{\mathrm{RB}}\left(\mathrm{gd}^{-1}\right)^{*}$ & -0.06 & 0.51 & 0.51 & -0.04 & 0.30 & 0.68 & 0.11 & 0.24 & 0.01 \\
\hline $\mathrm{PDIG}_{\mathrm{RB}}(\%)^{*}$ & -18.59 & 21.44 & 31.82 & -9.75 & 35.82 & 35.78 & 6.72 & 0.05 & 0.01 \\
\hline
\end{tabular}

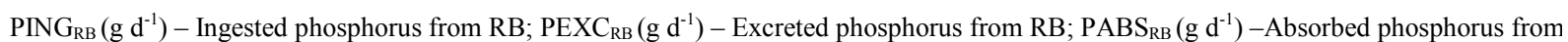
RB; $\mathrm{PDIG}_{\mathrm{RB}}(\%)$ - Digestible phosphorus from RB; Linear regression* $(\mathrm{P}<0.05)$.

different from zero $(\mathrm{P}<0.01)$. There was a relatively wide variation in estimates of endogenous $P$ losses determined by regression. Several factors may contribute to the variation in results. It is possible to highlight chemical and physical characteristics of food. This is evident when comparing endogenous losses from pea (160 $\mathrm{mgkg}^{-1} \mathrm{DMI}$; SHEN et al., 2002) or red rice $\left(725 \mathrm{mgkg}^{-1} \mathrm{DMI}\right.$; YANG et al., 2007), for example. However, even when analyzing the results of a single food, such as soybean meal, there are variable endogenous losses, such as 310 (FAN et al., 2001), 450 (AJAKAIYE et al., 2003) and $620 \mathrm{mgkg}^{-1}$ DMI (FANG et al., 2007).
True digestibility of $\mathrm{P}$ in RB was estimated at $47 \%$. This was the slope of the regression line, and was higher than the value reported in other studies and presented in food composition tables. In ROSTAGNO et al. (2011), for example, the true digestibility of $\mathrm{P}$ in $\mathrm{RB}$ is $28 \%$, while the standard digestibility is $23 \%$ in the NRC (2012). Content of true total digestible $\mathrm{P}$ of $\mathrm{P}$ in $\mathrm{RB}$ usually ranges between $20 \%$ and $30 \%$. This is justified because a significant portion of $\mathrm{P}$ is in the form of phytate, a molecule that pigs have difficulty digesting because they do not synthesize an enzyme capable of hydrolyzing it (ROJAS \& STEIN, 2012).

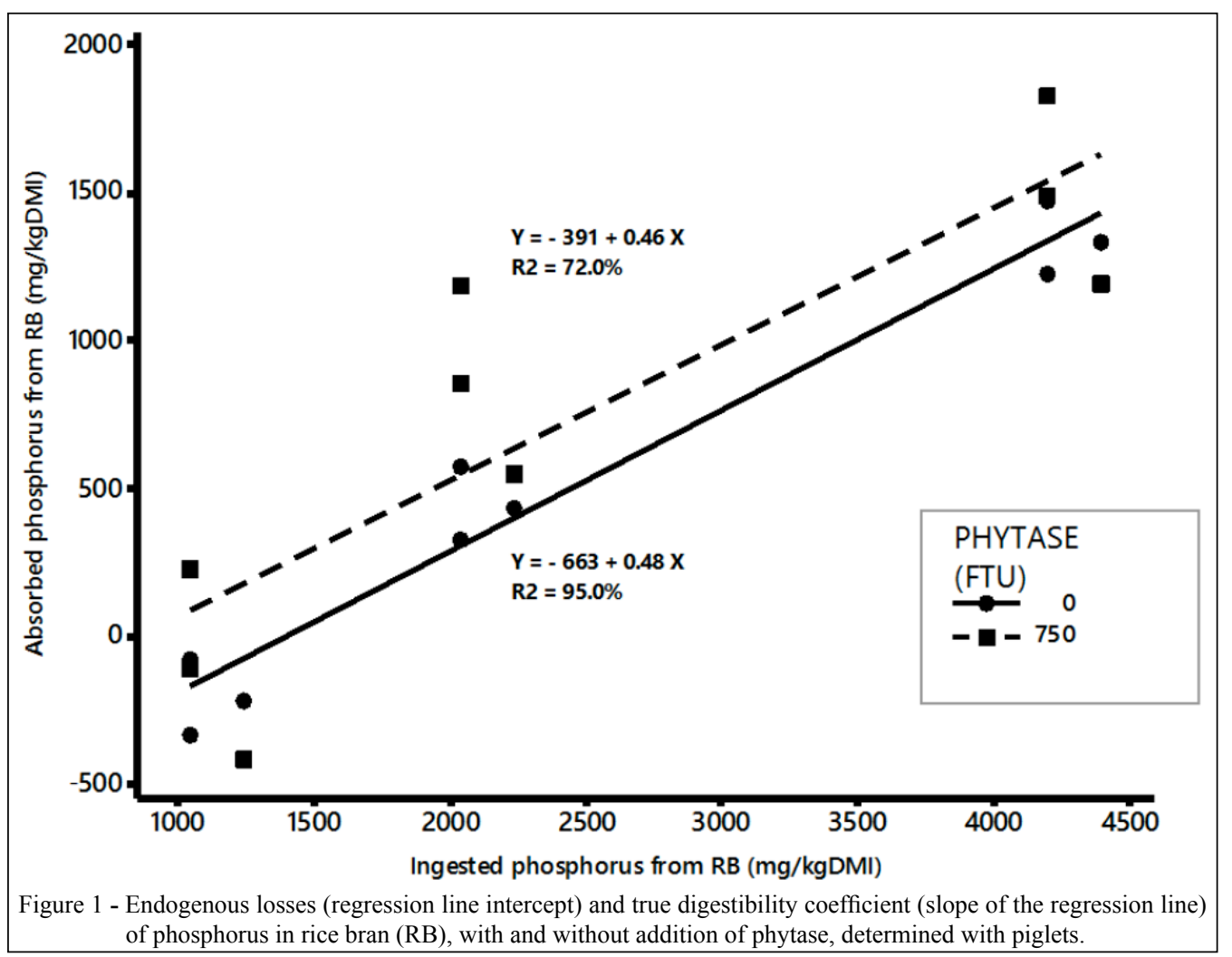

Ciência Rural, v.46, n.6, jun, 2016. 
Thus, while the value of $47 \%$ for $\mathrm{P}$ digestibility in RB is higher than that reported in other studies, it is within an expected theoretical amplitude. Whereas the proportion of $\mathrm{P}$ in the phytate molecule reported in RB ranges from $64 \%$ to $90 \%$ (SELLE et al., 2003; GODOY et al., 2005). Assuming that $75 \%$ of total $\mathrm{P}$ is bound to phytate (ROSTAGNO et al., 2011) and the digestibility coefficient is $80 \%$ and $30 \%$ for phytic acid and available P, respectively (KIES et al., 2006), it is possible to reach a digestibility coefficient of $43 \%$ for total P. Moreover, FIGUEIRÊDO et al. (2000) using the isotope dilution technique reported values near $40 \%$ and $68 \%$ using the isotope method with and without the presence of $1250 \mathrm{FTUkg}^{-1}$ of fungal phytase, respectively, which also suggested that the true total digestibility of $\mathrm{P}$ in RB may be higher than the figure usually cited in the literature (ROSTAGNO et al., 2011).

There was no effect of phytase on the true digestibility of $\mathrm{P}$ in RB. The reasons for these results are not clear because there are some reports showing that the addition of phytase increases the $\mathrm{P}$ digestibility of RB in growing pigs (FIGUEIRÊDO et al., 2000; TRUJILLO et al., 2010). The results cannot exclude live weight as one of the explanations for the lack of effect in this study, since piglets may present a high gastric pH (NARCY et al., 2012), reducing the hydrolytic activity of phytase.

Another possibility to lack of phytase effect could be the phosphorus intake above the requirements of piglets since a condition to observe when using the regression method is that the test nutrient intake must be below requirements (DILGER \& ADEOLA, 2006). However, assuming that the total apparent digestibility of total $\mathrm{P}$ in the diet is $53.8 \%$, the total consumption of digestible $\mathrm{P}$ was approximately $1.45 \mathrm{gd}^{-1}$, a value that represents about $70 \%$ of requirements for piglets within the weight range used in this paper (NRC, 2012).

\section{CONCLUSION}

We conclude that the addition of 750FTU of phytase does not influenced endogenous losses of phosphorus or the true digestibility of phosphorus in rice bran.

\section{BIOETHICS AND BIOSSECURITY COMMITTE APPROVAL}

The experimental protocol was reviewed and approved by the Ethics Committee in Animal Experimentation of the Universidade Federal de Santa Maria (UFSM) (Process n. 021/2013).

\section{REFERENCES}

AJAKAIYE, A. et al. Determination of true digestive utilization of phosphorus and the endogenous phosphorus outputs associated with soybean meal for growing pigs. Journal of Animal Science, v.81, n.11, p.2766-2775, 2003. Available from: <https://www. animalsciencepublications.org/publications/jas/articles/81/11/08 12766 ?highlight=\&search-result=1>. Accessed: Nov. 16, 2014. doi: /2003.81112766x.

ALMEIDA, F.N.; STEIN, H.H. Effects of graded levels of microbial phytase on the standardized total tract digestibility of phosphorus in corn and corn coproducts fed to pigs. Journal Animal Science, v.90, n.4, p.1262-1269, 2012. Available from: $<$ http://www.ncbi.nlm.nih.gov/pubmed/22100589>. Accessed: Nov. 19, 2014. doi: $10.2527 /$ jas.2011-4144

ALMEIDA, F.N.; STEIN, H.H. Standardized total tract digestibility of phosphorus in blood products fed to weanling pigs. Revista Colombiana de Ciências Pecuárias, v.24, n.4, p.617-622, 2011. Available from: <http://www.scielo.org. co/scielo.php?pid $=$ S0120-06902011000400006\& $\mathrm{script}=\mathrm{sci}$ arttext>. Accessed: Mar. 18, 2015.

AOAC (ASSOCIATION OF OFFICIAL ANALYTICAL CHEMISTS). Official methods of analysis. Arlington, 2005. p. 1141.

BOHLKE, R.A. et al. Calcium, phosphorus, and amino acid digestibility in low-phytate corn, normal corn, and soybean meal by growing pigs. Journal of Animal Science, v.83, n.10 p.2396-2403, 2005. Available from: < https://www. animalsciencepublications.org/publications/jas/articles/83/10/0 832396? highlight=\&search-result=1>. Accessed: Jan. 21, 2015. doi:/2005.83102396x.

DILGER, R.N.; ADEOLA, O. Estimation of true phosphorus digestibility and endogenous phosphorus loss in growing pigs fed conventional and low-phytate soybean meals. Journal of Animal Science, v.84. n.4, p.624-634, 2006. Available from: <https:// www.animalsciencepublications.org/publications/jas/articles/8 4/3/0840627?highlight $=\&$ search-result=1>. Accessed: Nov. 23, 2014.doi:/2006.843627x.

DERSJANT-LI, Y. et al. Phytase in non-ruminant animal nutrition: a critical review on phytase activities in the gastrointestinal tract and influencing factors. Journal of the Science of Food and Agriculture, v.95, n.5, p.878-896, 2014. Available from: $<$ http:// www.ncbi.nlm.nih.gov/pmc/articles/PMC4368368/>. Accessed: Oct. 23, 2015. doi: 10.1002/jsfa.6998.

FAN, M.Z. et al. Novel methodology allows simultaneous measurement of true phosphorus digestibility and the gastrointestinal endogenous phosphorus outputs in studies with pigs. Journal Nutritional Science, v.131, n.9, p.23882396, 2001. Available from: < http://jn.nutrition.org/ content/131/9/2388.long $>$. Accessed: May 10, 2015. doi: $0022-3166 / 01$.

FANG, R.J. el al. Comparison of the regression analysis technique and the substitution method for the determination of true phosphorus digestibility and faecal endogenous phosphorus losses associated with feed ingredients for growing pigs. Livestock Science, v.109, n.1-3, p.251-254, 2007. Available from: <http:// www.livestockscience.com/article/S1871-1413(07)00111-4/ pdf $>$. Accessed: Mar. 21, 2015. doi: http://dx.doi.org/10.1016/j. livsci.2007.01.108. 
FIGUEIRÊDO, A.V. et al. Effect of phytase on the biological availability of phosphorus by means of isotopic dilution technique, in whole rice meal based diets, for swines. Revista Brasileira de Zootecnia, v.29, n.1, p.177-182, 2000. Available from: $\quad<$ http://www.scielo.br/scielo.php?script=sci_arttext\&pid $=$ S1516-35982000000100024>. Accessed: Jan. 24, 2015. doi: $10.1590 / \mathrm{S} 1516-359820000001000241$.

GODOY, S. et al. Phytic phosphorus and phytase activity of animal feed ingredients. Interciencia, v.30, n.1, p.24-28, 2005. Available from: <http://scielo.org.ve/scielo.php?pid=S0378$18442005000100005 \&$ script $=$ sci_arttext $>$. Accessed: 24 Jan. 2015.

GOMES, T.R. et al. Effect of inclusion of rice bran in diets for piglets from 21 to 42 days of age. Archivos de Zootecnia, v.61, n.233, p.129-139, 2012. Available from: <http://scielo.isciii.es/scielo. php?script $=$ sci_arttext\&pid=S0004-05922012000100014\&lng= en\&nrm=iso\&tlng=en>. Accessed: Nov. 18, 2014. doi: 10.4321/ S0004-05922012000100014.

KIES, A.K. et al. Effect of graded doses and a high dose of microbial phytase on the digestibility of various minerals in weaner pigs. Journal of Animal Science, v.84, n.5, p.1169-1175, 2006. Available from: <https://www.animalsciencepublications. org/publications/jas/articles/84/5/0841169?highlight=\&searchresult $=1>$. Accessed: Jan. 18, 2015. doi: $/ 2006.8451169 x$.

MINITAB. Minitab Statistical Software. USA: State College PA, 2013. Release 16.1 for windows.

NARCY, A. et al. Modulation de I'utilisation digestive du phosphore chez le porcelet sevré: influence de I'apport de calcium et de phytese sur le $\mathrm{pH}$ et la solubilité des minéraux au niveau gastro-intestinal. Journées Recherche Porcina, v. 44, p.159-164, 2012 .

NRC (NATIONAL ACADEMY OF SCIENCE). Nutrient requirements of swine. 11.ed. Washington, D.C., 2012. 400p.
ROJAS, O.J.; STEIN, H.H. Digestibility o phosphorus by growing pigs of fermented and conventional soybean meal without and with microbial phytase. Journal of AnimalScience, v.90,n.5,p.1506-1512, 2012. Available from: $<$ https://www.animalsciencepublications.org/ publications/jas/abstracts/90/5/1506>. Accessed: May 10, 2015. doi: $10.2527 /$ jas.2011-4103.

ROSTAGNO, H.S. et al. Tabelas brasileiras para aves e suínos: composição de alimentos e exigências nutricionais. Viçosa: UFV, Departamento de Zootecnia, 2011. 251p.

SELLE, Total and phytate-phosphorus contents and phytase activity of Australian-sourced feed ingredients for pigs and poultry. Australian Journal of Experimental Agriculture, v.43, n.5, p.475-479, 2003. Available from: <http://www. publish.csiro.au/?paper=EA02155>. Accessed: May 10, 2015. doi: $10.1071 / \mathrm{EA} 02155$.

SHEN, Y. et al. Use of the regression analysis technique to determine the true phosphorus digestibility and the endogenous phosphorus output associated with corn in growing pigs. Journal of Nutrition, v.132, n.6, p.1199-1206, 2002. Available from: $<$ http://jn.nutrition.org/content/132/6/1199.full.pdf + html $>$. Accessed: Nov. 18, 2014.

TRUJILLO, J.H.A. et al. Phosphorus utilization in growing pigs fed a phosphorus deficient diet supplemented with a rice bran product and amended with phytase. Revista Colombiana de Ciências Pecuárias, v.23, n.4, p.429-443, 2010. Available from: <http://www.scielo.org.co/pdf/rccp/v23n4/v23n4a04.pdf >. Accessed: Nov. 18, 2014.

YANG, H. et al. True phosphorus digestibility and the endogenous phosphorus outputs associated with brown rice for wealing pigs measured by the linear regression analysis technique. Animal, v.1, n.3, p.213-220, 2007. Available from: <http://www.ncbi.nlm.nih. gov/pubmed/22444286>. Accessed: May 11, 2015. doi: 10.1017/ S1751731107257945. 